Article

\title{
Exploration of the Fluorescent Properties and the Modulated Activities against Sirtuin Fluorogenic Assays of Chromenone-Derived Natural Products
}

\author{
Hui Wen ${ }^{1,+} \mathbb{D}^{\circ}$, Nina Xue ${ }^{1,+}$, Feng $\mathrm{Wu}^{2}$, Yujun He ${ }^{1}$, Gang Zhang ${ }^{1}$, Zebin $\mathrm{Hu}^{3, *}$ and \\ Huaqing Cui $1, *$ (D) \\ 1 State Key Laboratory of Bioactive Substances and Function of Natural Medicine, Institute of Materia Medica, \\ Peking Union Medical College and Chinese Academy of Medical Sciences, Beijing 100050, China; \\ wenhui@imm.ac.cn (H.W.); angelnina@imm.ac.cn (N.X.); heyujun506@imm.ac.cn (Y.H.); \\ gzhang@imm.ac.cn (G.Z.) \\ 2 Institute of Aviation Medicine, Air Force, Beijing 100142, China; wufeng879@126.com \\ 3 National Institutes for Food and Drug Control, Beijing 100050, China \\ * Correspondence: huzbcmba@163.com (Z.H.); hcui@imm.ac.cn (H.C.); \\ Tel.: +86-10-6709-5597 (Z.H.); +86-10-6303-7952 (H.C.) \\ + These authors contributed equally to this paper.
}

Received: 18 March 2018; Accepted: 27 April 2018; Published: 2 May 2018

check for updates

\begin{abstract}
Chromenone-derived natural products include chromones (flavone, isoflavone) and coumarins. Chromenone compounds not only exhibit impressive biological activities, but also are an important resource of experimentally used fluorophores, such as, 7-amino-4-methylcoumarin (AMC). Various chromenone compounds have reported to have weak fluorescence, and this has the potential to interfere with the measurements during AMC fluorogenic assays and result in non-robust assay readouts. Several flavones and isoflavones were found as SIRT1 activators, while fluorogenic sirtuin assays utilized AMC labelled peptides as the substrates. In this study we investigated whether the fluorescent properties of chromenone-derived natural products interrupt the measurement of SIRT1/2 modulated activities. We found that the reported SIRT1 activators: flavones were detected with the SIRT1 activation activity, but isoflavones were not detected with SIRT1 activation activity, and instead that they were found to be fluorogenic compounds. Another chromenone compound, osthole, exhibited a moderate SIRT2 inhibitory activity with an $\mathrm{IC}_{50}$ of $10 \mu \mathrm{M}$. In conclusion, the fluorescent properties of these chromenone compounds do affect the measurement of the sirtuin activities of both inhibitors and activators. However, if the possible fluorescence properties are mitigated in the assay readout, these fluorogenic assays enable the screening of activity modulators.
\end{abstract}

Keywords: chromenone; isoflavone; osthole; AMC; fluorescence; fluorogenic assay; sirtuin; SIRT1 activator

\section{Introduction}

Flavonoids are a large family of natural products, which are mainly found and extracted from plants [1-3]. Chromenone-derived compounds belonging to the flavonoid family include chromones (flavones, isoflavones) and coumarins (Figure 1) [4,5]. Chromenone is recognized as a privileged scaffold in medicinal chemistry due to its advantageous drug-like properties and versatile binding properties [4,5]. Various chemical synthesis and modification of the structure of chromenones (chromones and coumarins) have been extensively studied and numerous pharmacological activities of these important scaffold have been revealed, such as, anti-inflammatory [6], anti-oxidant activity [5], cardiovascular and hepatic protection effects [4]. 


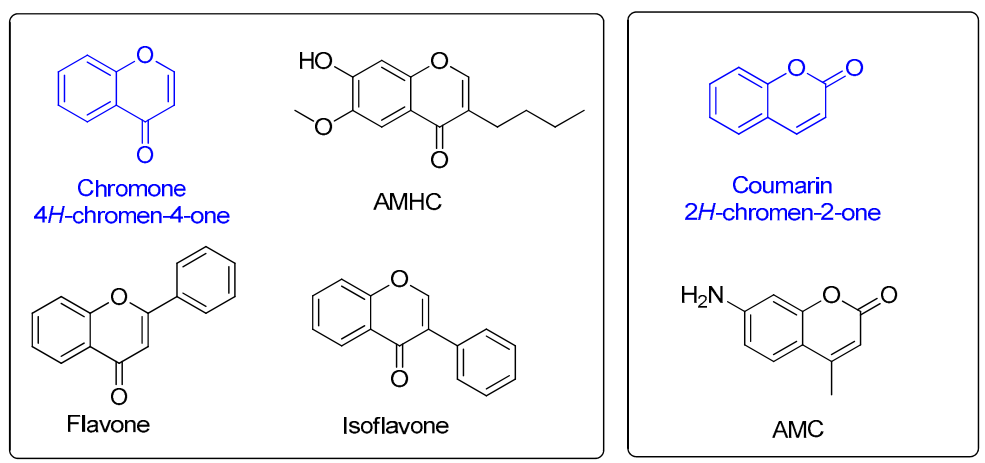

Figure 1. Chemical structures of chromenone derived compounds (chromone and coumarin). The left handside shows the structures of chromone and other chromone derived compounds, such as, flavones, isoflavone and 3-alkyl-6-methoxy-7-hydroxychromone (AMHC). The right handside shows the structures of coumarin and 7-amino-4-methylcoumarin (AMC).

Interestingly, many chromenone-derived compounds were found to be fluorogenic $[7,8]$, with the 7-hydroxycoumarin scaffold being used as the main experimental chromenone fluorophore $[9,10]$. Commercially available 7-amino-4-methylcoumarin (AMC) is commonly used in various biological studies, and in particular AMC was used to develop a fluorescent turn-on enzymatic assays to study a large range of proteins including histone deacetylase (HDAC) [11], sirtuin (SIRT) [12], amidase [13], transglycosylase [10], and alkaline phosphatase (ALP) [14]. 7-Hydroxyisoflavones and 3 -hydroxyflavones also exhibit fluorescence in biological buffers $[15,16]$. In our previous studies, we reported the development of 3-alkyl-6-methoxy-7-hydroxychromones (AMHC) as a fluorogenic scaffold for biological studies, which displays comparable fluorescent properties to AMC [7]. Notably, both AMC and AMHC are chromenone-derived compounds, and they have similar excitation and emission wavelengths $\left(E_{\mathrm{x}}=360 \mathrm{~nm}, E_{\mathrm{m}}=460 \mathrm{~nm}\right.$ ) as other fluorogenic chromenone compounds.

The sirtuin family of enzymes are a class III histone deacetylase (HDAC) that catalyzes the removal of acetyl groups from a lysine residue found on endogenous substrates $[17,18]$. The sirtuin family includes seven enzymes, however SIRT1 and SIRT2 are the most well studied members of this family. SIRT1 involves cell metabolism, and regulates fat and cholesterol metabolism, with SIRT1 deficiency in mice resulting in insulin resistance $[19,20]$. SIRT2 functions in the cellular activities, such as, necrosis and apoptosis. Genetic knockout of SIRT2 and small molecule SIRT2 inhibitors both show neuroprotection against the neurotoxicity observed in a Parkinson's disease cell model and a transgenic mouse model [12,21,22].

Due to their importance, sirtuin enzymatic assays have been developed employing different strategies [23-28], such as, using FRET assays and fluorescent turn-on assays. However, the most commonly used sirtuin enzymatic assay were developed using AMC-labelled peptide serving as the substrate, in which the lysine was acetylated (Figure 2) [12,27]. Once the peptide was deacetylated by the sirtuin enzyme, the peptide was digested by trypsin to release the fluorescent tag and quantified. In this assay, 7-amino-4-methylcoumarin (AMC) was used as the fluorophore.

Many sirtuin modulators have been discovered, which include SIRT1 activators and various sirtuin inhibitors (Figure 3) [12,29-38]. SIRT1 activators were initially screened from flavonoid-derived natural products. Among the first generation of naturally sourced SIRT1 activators, resveratrol exhibited the best SIRT1 activation activity and it was shown to be able to extend the lifespan of yeast [33]. Notably, several flavones and isoflavones were also reported as SIRT1 activators [33,36]. The pharmacological effects of SIRT1 activators have been observed in animal models with remarkable health benefits, although the mechanism of action of these SIRT1 activators is still not established [39]. On the other hand, many compounds have been developed as sirtuin inhibitors [12,29]. Among them, some of them were designed as selective inhibitors against a certain member of sirtuin family, 
while others exhibited pan-inhibition of the entire family. Notably, a series of chromenone compounds were found to be potent SIRT2 selective inhibitors [30].

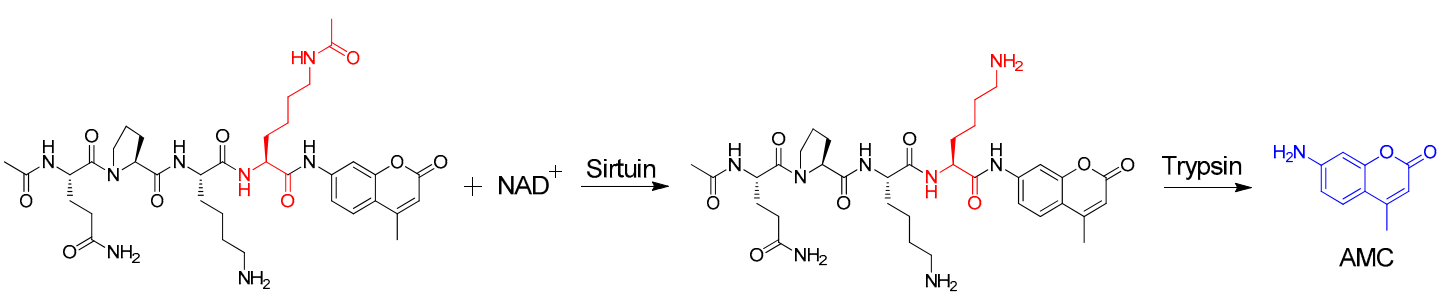

Figure 2. The principle of AMC labelled fluorescence turn-on sirtuin assay. The AMC labelled peptide containing an acetylated lysine, in which the fluorescence is quenched. This peptide was used as the substrates in the assay and can be deacetylated by sirtuin enzyme in the presence of $\mathrm{NAD}^{+}$. The deacetylated peptide is then digested by trypsin to release the free AMC, which has turn-on fluorescence. Thus, the measured fluorescence intensity can be used as a readout for the activity of the sirtuin enzyme.

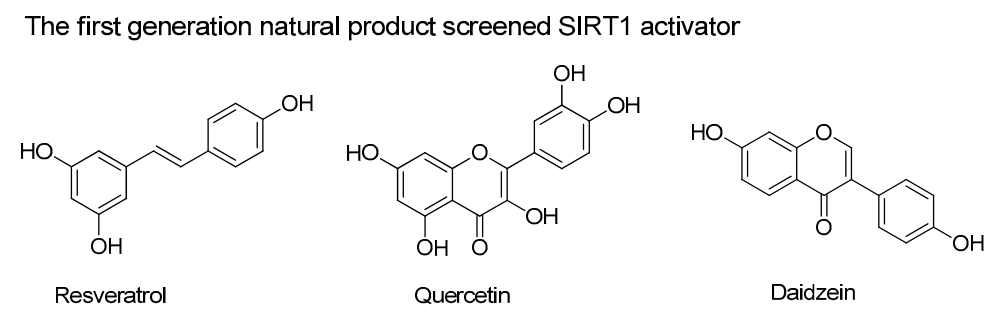

Selective and non-selective sirtuin inhibitor<smiles>CCCCC[C@@H]1CC(=O)c2cc(Cl)cc(Br)c2O1</smiles><smiles>NC(=O)c1ccccc1Nc1cccc(OCCc2cccc(F)c2)c1</smiles>

Chroman-4-one

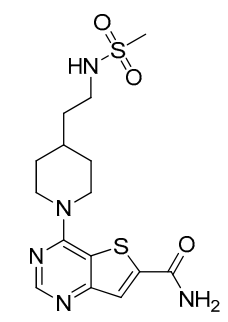

Figure 3. The structures of selected SIRT1 activators and SIRT1/2 inhibitors. The first generation SIRT1 activators were discovered from screens of flavonoids natural products. Resveratrol is one of the most potent SIRT1 activators discovered so far, while flavones (quercetin) and isoflavones (daidzein) were also found with SIRT1 activation activity. For sirtuin inhibitors, many synthesized compounds were reported with selective or non-selective sirtuin inhibitory activities.

Sirtuin fluorogenic assays were developed using AMC as the fluorescent tag. Considering the similar fluorescence emission and excitation wavelengths of AMC and some fluorogenic chromenone compounds, in this study we investigated the fluorescence properties and sirtuin modulated activities of chromenone compounds in order to investigate how the fluorescence properties can affect the measurement of fluorogenic enzymatic activities of chromenone compounds.

\section{Results and Discussion}

\subsection{The Fluorescence Properties of Chromenone Derived Natural Products}

A group of chromenone derived natural products (Table 1), including flavones, isoflavones and coumarins, were collected and initially screened for fluorescent properties. The maximum excitation 
wavelength, emission wavelength and the fluorescent quantum yield of these compounds were measured in aqueous PBS buffer ( $\mathrm{pH}$ 7.4). We found that several naturally derived chromenone compounds: formononetin, daidzein and calycosin showed clear fluorescence in PBS buffer, with the maximum excitation and emission wavelengths in the range of $E_{\mathrm{x}}(338-348 \mathrm{~nm})$ and $E_{\mathrm{m}}(478-490 \mathrm{~nm})$, which is close to that of $\operatorname{AMC}\left(E_{\mathrm{x}}=360 \mathrm{~nm}, E_{\mathrm{m}}=460 \mathrm{~nm}\right)$. Another flavonoid compound, resveratrol, is also fluorogenic, and has $E_{\mathrm{x}}=304 \mathrm{~nm}, E_{\mathrm{m}}=400 \mathrm{~nm}$, which differs slightly from AMC. The remaining compounds exhibited no or marginal fluorescence in PBS buffer.

Natural products are a major chemical resource used for hit finding in drug discovery. Interestingly, many natural products are fluorogenic compounds, however they usually have relatively low fluorescent quantum yields. Several commonly used experimental fluorophores with enhanced fluorescence properties were modified from the fluorogenic natural product [7]. In this study, we chose natural products as the targeted samples. For compound selection, we included several previously reported chromenone derived SIRT1 activators $[33,36]$, such as, flavone compounds (quercetin, luteolin, kaempferol), isoflavone compounds (daidzein) and other flavonoids (resveratrol). This should allow for a better comparison of the fluorescent properties and SIRT1/2 modulation activities of this class of compounds. For the examination of fluorescence properties, we detected and recorded the maximum $E_{\mathrm{x}}$ and $E_{\mathrm{m}}$, which will be used to compare with that of AMC. We also measured and compared the fluorescence quantum yields of chromenone compounds (around 0.05 in PBS buffer) [7]. The excitation and emission fluorescence spectra of the fluorescent compounds were included in the supplementary file. Interestingly, three previously reported flavone derived SIRT1 activators (quercetin, luteolin, kaempferol) are all non-fluorogenic compounds in PBS buffer. However, we observed that the isoflavone derived SIRT1 activator daidzein and the flavonoid compound resveratrol are fluorogenic compounds.

Table 1. The fluorescence properties and SIRT1/2 activities of chromenone compounds.

\begin{tabular}{|c|c|c|c|c|c|c|}
\hline \multirow{2}{*}{ Compound } & \multirow{2}{*}{ Structure } & \multicolumn{3}{|c|}{ Fluorescence } & \multicolumn{2}{|c|}{ Activity $(10 \mu \mathrm{M})$} \\
\hline & & $E_{\mathbf{x}}$ & $E_{\mathrm{m}}$ & $\phi$ & SIRT1 & SIRT2 \\
\hline 1 & Resveratrol & 304 & 400 & 0.16 & 11.60 & 0.87 \\
\hline 2 & & - & - & - & 0.76 & 0.72 \\
\hline 3 & & - & - & - & 0.95 & 0.83 \\
\hline 4 & & - & - & - & 0.82 & 0.47 \\
\hline 5 & & - & - & - & 1.21 & 0.75 \\
\hline & Luteolin & & & & & \\
\hline
\end{tabular}


Table 1. Cont.

\begin{tabular}{|c|c|c|c|c|c|c|}
\hline \multirow{2}{*}{ Compound } & \multirow{2}{*}{ Structure } & \multicolumn{3}{|c|}{ Fluorescence } & \multicolumn{2}{|c|}{ Activity $(10 \mu \mathrm{M})$} \\
\hline & & $E_{\mathbf{x}}$ & $E_{\mathrm{m}}$ & $\phi$ & SIRT1 & SIRT2 \\
\hline 6 & ercetin & - & - & - & 3.22 & 0.80 \\
\hline 7 & Kaempferol & - & - & - & 1.10 & 0.86 \\
\hline 8 & Catechin & - & - & - & 0.89 & 0.80 \\
\hline 9 & Baicalin & - & - & - & 0.65 & 0.81 \\
\hline 10 & Rutin & - & - & - & 0.82 & 0.76 \\
\hline 11 & & - & - & - & 0.90 & 0.79 \\
\hline 12 & Hesperidin & - & - & - & 0.92 & 0.79 \\
\hline 13 & Daidzein & 340 & 490 & 0.05 & 0.92 & 0.80 \\
\hline 14 & & 338 & 488 & 0.08 & 0.80 & 0.95 \\
\hline 15 & Calycosin & 340 & 490 & 0.03 & 0.87 & 0.83 \\
\hline
\end{tabular}


Table 1. Cont

\begin{tabular}{|c|c|c|c|c|c|c|}
\hline \multirow{2}{*}{ Compound } & \multirow{2}{*}{ Structure } & \multicolumn{3}{|c|}{ Fluorescence } & \multicolumn{2}{|c|}{ Activity $(10 \mu \mathrm{M})$} \\
\hline & & $E_{\mathbf{x}}$ & $E_{\mathrm{m}}$ & $\phi$ & SIRT1 & SIRT2 \\
\hline 16 & Genistein & - & - & - & 1.00 & 0.72 \\
\hline 17 & Glycitein & 348 & 478 & 0.04 & 0.79 & 0.66 \\
\hline 18 & Tectorigenin & - & - & - & 0.81 & 0.77 \\
\hline 19 & Daidzin & - & - & - & 1.00 & 0.93 \\
\hline 20 & & - & - & - & 0.96 & 0.93 \\
\hline 21 & Tectoridin & - & - & - & 0.93 & 0.88 \\
\hline
\end{tabular}

Compounds SRT1720 (S1129) and AGK2 (selleckchem, S7577) were used as the reference compounds to evaluate the SIRT1/2 assays.

\subsection{The SIRT1/2 Activities of Chromenone Derived Natural Products}

Next, we screened the SIRT1/2 activity of chromenone compounds (Table 1). All compounds were dissolved to a final screening concentration of $10 \mu \mathrm{M}$. For the SIRT1 activities, we found that resveratrol showed potent active SIRT1 activation (activation rate $=11.6$ ). Flavone compounds (quercetin, luteolin, kaempferol) also displayed low activation activity, but for the remaining flavone compounds, we did not observe any obvious activation activity toward SIRT1. No isoflavone compound with SIRT1 activation activities was detected, although some of them, such as, daidzein, were previously reported to have SIRT1 activation activities. However, baicalin showed weak SIRT1 inhibitory activity. For SIRT2 activities, no compound tested displayed any SIRT2 activation activity. Most of the compounds tested were found to have weak SIRT2 inhibitory activities. However, osthole was found to have moderate SIRT2 inhibitor ( $47 \%$ enzymatic activity at the concentration of $10 \mu \mathrm{M})$.

Sirtuin fluorogenic assays have been developed utilizing various AMC labelled peptides as the substrate, with this assay being routinely used to screen for small molecule SIRT1/2 modulators [27]. The first generation of SIRT1 activators were screened using the commercial Fluor de lys assay kit (ENZO Company, New York, NY, USA, BML-AK500-0001, $E_{\mathrm{x}}=360 \mathrm{~nm}, E_{\mathrm{m}}=460 \mathrm{~nm}$ ), which was initially developed as a HDAC assay and included two amino acid AMC labeled peptide as the substrate [28]. However, currently various 4-mer peptides are more often used in these sirtuin assays. It is clear that different peptide substrates have differing $K_{m}$ in sirtuin assay, and this will subsequently affect the detected activity of various modulators. Therefore in this study we only observed weak 
or marginal SIRT1 activation activity for the flavones compounds (quercetin, luteolin, kaempferol), although these were previously reported as having potent SIRT1 activation activities. However, and in accordance to previously published work, resveratrol still acted as very potent SIRT1 activator in our study. Unfortunately, the isoflavones derived compounds did not show any activation activity toward SIRT1 even though they were reported as having clear SIRT1 activation activity $[33,34,38]$.

The fluorophore of AMC was used in our sirtuin fluorogenic assays, with detection carried out at specific wavelengths $\left(E_{\mathrm{x}}=360 \mathrm{~nm}, E_{\mathrm{m}}=460 \mathrm{~nm}\right)$ [12]. Due to the similar excitation and emission wavelengths of fluorogenic chromenone compounds with AMC (Table 1) [7], we reasoned that the observed fluorescence from chromenone compounds might cause the false evaluation of these sirtuin modulators. In particular we were concerned that the final fluorescence turn-on rate was partially of the substrate peptide $(50 \mu \mathrm{M})$. In comparison, the concentration of screened compounds was usually set with $10-50 \mu \mathrm{M}$. Thus, possible fluorogenic compounds might cause the fake activation but hide the potent inhibition.

In this study, which contained compounds with known fluorescence included resveratrol and several isoflavones derived compounds, we removed the fluorescent background from the assay readout to calculate the enzymatic activity (Table 1). Our results showed that several flavones compounds (quercetin, luteolin, kaempferol) are non-fluorogenic and acted as SIRT1 activators and SIRT2 inhibitors. However, the isoflavone compounds (formononetin, calycosin, glycitein) are reasonably fluorogenic. If the fluorescent signals of these compounds were removed, we observed that they exhibited weak SIRT1 and SIRT2 inhibitory activities instead of being as SIRT1 activators. Thus, the possible fluorescence properties of these chromenone compounds do indeed interrupt and interfere with the regular performance of AMC applied sirtuin fluorogenic assay, and thus affects the robustness of the readout obtained.

\subsection{The Inhibitory Mode of Osthole against SIRT2}

We applied the aforementioned AMC used SIRT1/2 fluorogenic assay to screen a series of chromenone-derived compounds. This screen identified several compounds with appreciable activity, however, we decided to focus our attention on osthole, which showed moderate SIRT2 inhibitory activity (Table 1). In order to understand the bona fide inhibitory mode of osthole against SIRT2, we performed the enzymatic inhibitory assay with different concentrations of osthole, and found that osthole showed potent SIRT2 inhibition activity with an IC $_{50}$ of $10 \mu \mathrm{M}$ (Figure $4 \mathrm{~A}$ ). As there are two substrates, $\mathrm{NAD}^{+}$and the peptide, used in the assay, we decided to investigate the competitive relationship between substrate peptide and osthole. We saturated the system with $\mathrm{NAD}^{+}$, and then varied the concentration of the peptide used. We measured the enzymatic kinetics at different inhibitor concentrations, and plotted the graph of $1 /$ rate (v) versus 1 /peptide with differing inhibitor concentrations. We observed that osthole was a competitive against the substrate peptide (Figure 4B). We then turned our attention on $\mathrm{NAD}^{+}$competition and saturated the assay with high concentration of peptide and subsequently added various concentrations of $\mathrm{NAD}^{+}$to measure the enzymatic kinetics at each inhibitor concentration, and plotted the $1 /$ rate $(\mathrm{v})$ versus $1 / \mathrm{NAD}^{+}$. The results show that osthole is a non-competitive inhibitor against $\mathrm{NAD}^{+}$(Figure $4 \mathrm{C}$ ). The mode of action study of osthole against the substrates of SIRT2 assays suggests osthole competes with the substrate peptide binding events at the peptide-binding site within the SIRT2 active site, but does not affect the binding of $\mathrm{NAD}^{+}$to the enzyme.

We next wanted to use in silico methods to understand the binding mode of osthole inside the active site of SIRT2 [40]. For the docking studies, the Accelrys Discovery Studio Visualizer 4.0 (Accelrys, San Diego, CA, USA) and Pymol 0.99 was utilized for interaction visualization, and X-ray crystallographic structure of SIRT2 (PDB Code: 1j8f) were obtained from the protein databank (PDB). The lowest energy conformations were selected and the ligand interactions with SIRT2 were determined. These calculations showed that osthole formed hydrogen bond interactions with $\mathrm{N}-\mathrm{H}$ of ILE169 residue, O-H of ASP170 and N-H of PHE96, respectively. The phenyl ring of osthole showed 
weak $\pi-\pi$ interaction with the phenyl ring of PHE96. The alkene chain of osthole showed hydrophobic or Van der Waals interactions with the hydrophobic groups of LEU103, PHE119, LEU134 and LEU138 (Figure 4D-E). In addition, the docking study also showed that osthole shared the same binding pocket with the substrate peptide, which occupied the lysine position on C-terminal of the substrate peptide (Figure 4F).

As we summarized above, the fluorescence properties of chromenone compounds do affect the measurement of AMC applied fluorogenic assays through fluorescence interference. In this study, our SIRT1/2 fluorogenic assay showed that resveratrol was a potent SIRT1 activator and osthole as a moderate SIRT2 inhibitor. The activation mechanism of resveratrol toward SIRT1 has been intensively studied by many research groups although the underlying mechanism is still under investigation $[36,37,39]$. In order to more thoroughly understand the mode of inhibition of osthole against SIRT2, we decided to characterize the enzymatic inhibition mechanism of ostholes against SIRT2. Osthole competes with the peptide substrate within the peptide binding site, but does not bind to $\mathrm{NAD}^{+}$binding area. Particularly, computation methods also revealed osthole occupied the space of the peptide substrate, which agreed the kinetic study. All of the above data prove the bona fide inhibition of osthole against SIRT2. Thus, if the possible fluorescence properties of chromenone compounds were taken into consideration and therefore mitigated, AMC applied fluorogenic assays enable the screening of bona fide enzyme modulators.

A

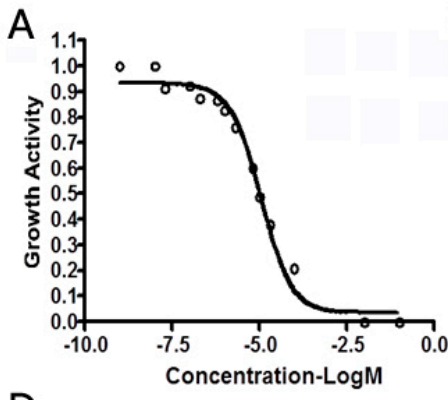

D

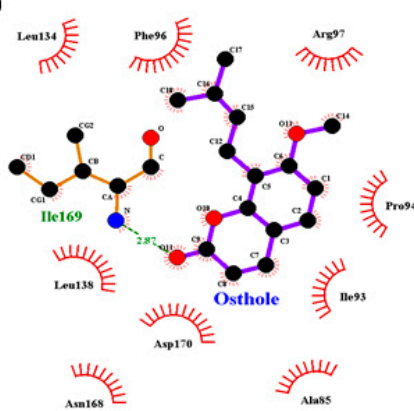

B

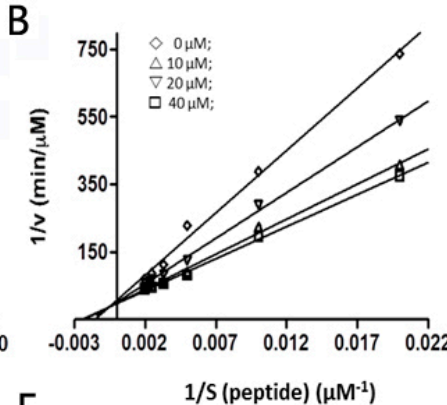

E

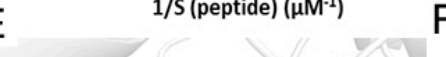

C

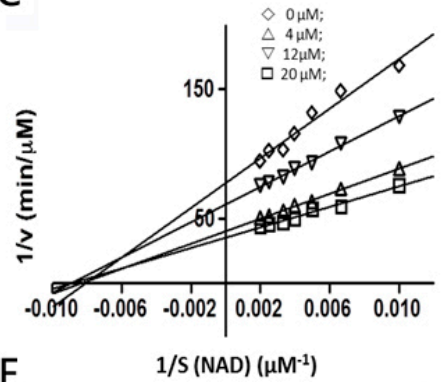

F

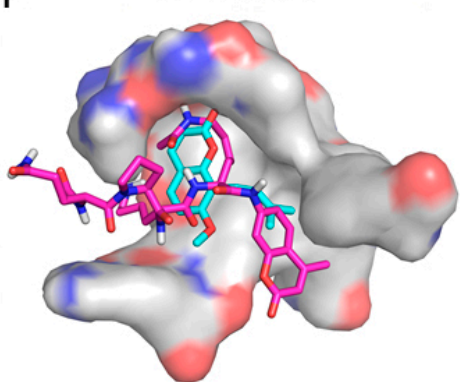

Figure 4. The inhibition mode study of osthole against SIRT2. (A) The measurement of IC $_{50}$ of osthole against SIRT2. Osthole was used from $0,0.05,0.1,0.16,0.5,0.63,1,5,10,50,100 \mu \mathrm{M}$. (B) The peptide substrate was used at various concentrations $(0,50,100,200,300,400$ and $500 \mu \mathrm{M})$ and osthole was used at $0(\diamond), 10 \mu \mathrm{M}(\triangle), 20 \mu \mathrm{M}(\nabla), 40 \mu \mathrm{M}(\square)$ with $\mathrm{NAD}^{+}$held at $0.5 \mathrm{mM}$. (C) NAD ${ }^{+}$was used at the concentrations $(0,100,150,200,250,300,400$ and $500 \mu \mathrm{M})$ and osthole was used at $0(\diamond), 10 \mu \mathrm{M}$ $(\triangle), 20 \mu \mathrm{M}(\nabla), 40 \mu \mathrm{M}(\square)$ with the peptide substrate held at $0.35 \mathrm{mM}$. (D,E) Docking study of osthole binding in the active center of SIRT2. (F) The docking study shows that osthole occupy the space of peptide substrates in the active center of SIRT2. The cyan compound represent osthole, the purple compound is the peptide substrate. Accelrys discovery studio visualizer 4.0 and Pymol 0.99 were used for the studied, and crystal structure of SIRT2 was selected as PDB Code: 1j8f. 


\section{Materials and Methods}

\subsection{The Chromenone Derived Natural Products}

All chromenone compounds with the purity of more than $95 \%$ were purchased from the Beijing Shiji-Aoke Biotechnology Co. (Beijing, China) and the Shanghai Jingke Chemistry Technology Co. (Shanghai, China).

\subsection{Comparison of Fluorescent Properties of Chromenone Derived Natural Products}

To obtain fluorescence excitation and emission spectra, we dissolved compounds in PBS (pH 7.4) at a concentration of $10 \mu \mathrm{M}$. For all compounds, we first set the $\lambda_{\text {em }}$ to get the maximum excitation wavelength, we then set $\lambda_{\mathrm{ex}}$ to obtain the maximum emission wavelength [9,41-43].

The calculation of fluorescent quantum yield. Fluorescence quantum yield was recorded using a comparative method of Williams et al. [44] The detection was carried out in PBS buffer (pH 7.4) at the concentration of $0.5 \mu \mathrm{g} / \mathrm{mL}$ using quinine sulfate $\left(0.5 \mu \mathrm{g} / \mathrm{mL}\right.$ in $\left.0.1 \mathrm{M} \mathrm{H}_{2} \mathrm{SO}_{4}, \Phi=0.54\right)$ as a reference. The quantum yield was calculated using the following equation:

$$
\Phi_{\mathrm{X}}=\Phi_{\mathrm{ST}}\left(A_{S T} F_{x} / A_{X} F_{S T}\right)\left(n_{X} / n_{S T}\right)^{2}
$$

where the subscripts $X$ and $S T$ denote test and standard respectively, $\Phi$ is the fluorescence quantum yield, $A$ is the absorbance at the excitation wavelength, $F$ is the area under the emission curve, and $n$ is the refractive index of the solvents used. For the tested compounds and the standard, the excitation wavelength was at $345 \mathrm{~nm}$ while keeping the absorption below 0.05 .

\subsection{The Purification of SIRT1 and SIRT2 Recombinant Proteins}

The ORF length of human SIRT1 (part) and SIRT2 (whole) was cloned into the expression vector pET28a [12,27,32]. The primers of SIRT1 were: 5'-tatggatccatggcggacgaggcggccetcgcctt-3', and 5'tatgcggccgcactatgatttgtttgatggatagt-3'; The primers of SIRT2 were: $5^{\prime}$-tatggatccatggcagagccagaccct ctcacctctgga-3', and 5'-tatgcggccgcatcactggggtttctcctctctgtt- $3^{\prime}$. The plasmids were separately transformed into E. coli BL21 (DE3) cells, and cultured the E. coli to be OD600 of 0.6, the E. coli was induced with $1 \mathrm{mM}$ isopropyl $\beta$-D-thiogalactoside (IPTG) and cultured for $6 \mathrm{~h}$ at $18{ }^{\circ} \mathrm{C}$. The cultures were harvested by centrifugation and the cell pellets were stored at $-20{ }^{\circ} \mathrm{C}$. The cell pellets were suspended in $15 \mathrm{~mL}$ binding buffer ( $50 \mathrm{mM}$ Tris- $\mathrm{HCl} \mathrm{pH}$ 8.0, $300 \mathrm{mM} \mathrm{NaCl})$. Cells were sonicated on ice for $5 \mathrm{~min}$ and centrifuged at $10,000 \mathrm{rpm}$ for $20 \mathrm{~min}$ at $4{ }^{\circ} \mathrm{C}$. The recombinant proteins were included in the supernatant. The clear supernatant was then applied to a $\mathrm{Ni}^{2+} \mathrm{NTA}$-agarose matrix (Qiagen, Hilden, Germany) column equilibrated with binding buffer (50 mM Tris- $\mathrm{HCl}$ pH 8.0, $300 \mathrm{mM} \mathrm{NaCl}$ ). The column was washed using the binding buffer to remove all of the unbound proteins. Then the bound proteins were eluted with a linear gradient of $0-200 \mathrm{mM}$ imidazole. Fractions containing

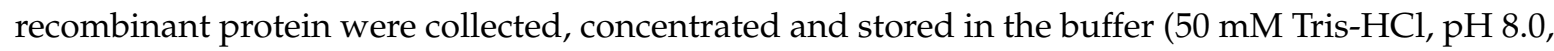
$265 \mathrm{mM} \mathrm{NaCl}, 0.2 \mathrm{mM}$ DTT, and 10\% glycerol) at $-20{ }^{\circ} \mathrm{C}$.

\subsection{Sirtuin Inhibition Assay}

SIRT1/2 enzymatic assay was performed using the substrate peptide of Ac-Gln-Pro-Lys\{Lys-(Ac)\}-AMC [12]. The assay was determined in $60 \mu \mathrm{L}$ assay buffer (25 mM Tris-HCl, pH 8.0, $137 \mathrm{mM}$ $\mathrm{NaCl}, 2.7 \mathrm{mM} \mathrm{KCl}$, and $1 \mathrm{mM} \mathrm{MgCl}_{2}$ and $1 \mathrm{mg} / \mathrm{mL} \mathrm{BSA}$ ), $500 \mu \mathrm{M} \mathrm{NAD}^{+}, 50 \mu \mathrm{M}$ peptide substrate and $1.0 \mu \mathrm{g}$ recombinant SIRT1 or SIRT2 protein. Various concentrations of screened compounds were added into the enzymatic assay (volume $<0.3 \mu \mathrm{L}$ ). The assay was incubated at $37^{\circ} \mathrm{C}$ for $2 \mathrm{~h}$. To each well was added another $60 \mu \mathrm{L}$ assay buffer (50 mM Tris- $\mathrm{HCl}, \mathrm{pH} 8.0,100 \mathrm{mM} \mathrm{NaCl}$ ), which contains $10 \mu \mathrm{L}$ trypsin $(60,000 \mathrm{BAEE} / \mathrm{mL})$ and $2 \mu \mathrm{L}$ SIRT2 inhibitor nicotinamide $(120 \mathrm{mM})$. The reaction were mixed and incubated at $37^{\circ} \mathrm{C}$ for $20 \mathrm{~min}$. The fluorescence was measured on a plate reader with excitation at $360 \mathrm{~nm}$ and emission at $460 \mathrm{~nm}$. The $\mathrm{IC}_{50}$ calculation of SIRT2 inhibitor was calculated using the 
GraphPad Prism software (5, GraphPad Software Inc., La Jolla, CA, USA). For each concentration of osthole $(0,0.05,0.1,0.16,0.5,0.63,1,5,10,50,100 \mu \mathrm{M})$, at least two wells were performed to calculate the average parameter. For these fluorogenic compounds, the fluorescence background from the screened compounds were specially detected and removed from the final calculation of the fluorescence intensities.

\subsection{The Inhibition Mode Study of Osthole against SIRT2}

For the inhibition mode of osthole against SIRT2, the assay was carried out with the condition listed above, but the concentrations of two substrates (NAD ${ }^{+}$and peptide substrate) were varied [12]. For the inhibition mode against peptide substrate, $500 \mu \mathrm{M} \mathrm{NAD}^{+}$and various concentrations of peptide substrates $(0,50,100,200,300,400$ and $500 \mu \mathrm{M})$ were used in the assay. Under this assay conditions, different concentrations of osthole $(0,10,20,40 \mu \mathrm{M})$ were added into SIRT2 assay to study the effect of these inhibitors toward to the assignment of the assay. For each condition, 2 wells of assays were performed. The enzyme kinetics were measured, calculated and reflected by the graph of $1 / \mathrm{v}$ versus $1 /$ peptide. For the inhibition mode against $\mathrm{NAD}^{+}, 350 \mu \mathrm{M}$ peptide and various concentrations of $\operatorname{NAD}^{+}(0,100,150,200,250,300,400$ and $500 \mu \mathrm{M})$ were used in the assay. Under this assay conditions, various concentrations of osthole $(0,10,20,40 \mu \mathrm{M})$ were added into SIRT2 assay to study the effect of these inhibitors toward to the assignment of the assay. For each conditions, 2 wells of assays were performed. The enzyme kinetics were measured, calculated and reflected by the graph of $1 / \mathrm{v}$ versus $1 / \mathrm{NAD}^{+}$[12]. The inhibition mode were calculated by fitting the data obtained at different substrate of peptide or $\mathrm{NAD}^{+}$under various concentrations of inhibitors to the Lineweaver-Buck double reciprocal plot:

$$
1 / \mathrm{V}_{0}=\left(K_{\mathrm{m}} / \mathrm{V}_{\max }\right) \times(1 /[\mathrm{S}])+1 / \mathrm{V}_{\max }
$$

\subsection{The Docking Study of Osthole Binding to SIRT2}

For the docking studies, the Accelrys Discovery Studio Visualizer 4.0 and Pymol 0.99 was utilized for interaction visualization [40], and X-ray crystallographic structure of SIRT2 (PDB Code:1j8f) was obtained from the protein databank (PDB) [22]. PDB protein and molecules were prepared by adding hydrogen, adding missing residues, and converting to pdbqt format. Molecule was docked using Vina with exhaustiveness grade 8, with up to 9 poses saved per molecule. The docking procedure was carried out for the unchanged conformation of the receptor and flexible ligand molecules.

\section{Conclusions}

Chromenone derived compounds are a class of privileged scaffolds within medicinal chemistry, with many chromenone compounds exhibiting impressive biological activities. Interestingly, chromenone compounds are also the main sources for experimental fluorophores. Several chromenone compounds have been well recognized as commercial fluorophores, such as AMC and AMHC. In order to accurately define the modulation activities of chromenone compounds when screened in AMC fluorogenic assays, we investigated SIRT1/2 modulated activities and fluorogenic properties of chromenone-derived natural products. We found that the fluorescent properties of chromenone-derived natural products do indeed affect the performance of AMC-detected sirtuin activity assays. However, if the possible fluorescence properties of chromenone compounds are mitigated and cancelled in the assay readout, these fluorogenic assays enable the correct screening of activity modulators.

Author Contributions: H.C. and Z.H. conceived and wrote the paper; H.W., N.X., F.W., G.Z. and Y.H. performed the experiments, analyzed the data.

Acknowledgments: This work was financially supported by National Science and Technology Major Projects for "Major New Drugs Innovation and Development" (2015ZX09102007-016-003), National Natural Science Foundation of China (81472396), CAMS Innovation Fund for Medical Sciences (2017-I2M-1-010). 
Conflicts of Interest: The authors declare no conflict of interest.

\section{References}

1. Teles, Y.C.F.; Souza, M.S.R.; Souza, M.F.V. Sulphated Flavonoids: Biosynthesis, Structures, and Biological Activities. Molecules 2018, 23, 480. [CrossRef] [PubMed]

2. Mozaffarian, D.; Wu, J.H.Y. Flavonoids, Dairy Foods, and Cardiovascular and Metabolic Health: A Review of Emerging Biologic Pathways. Circ. Res. 2018, 122, 369-384. [CrossRef] [PubMed]

3. Gutierrez-Grijalva, E.P.; Picos-Salas, M.A.; Leyva-Lopez, N.; Criollo-Mendoza, M.S.; Vazquez-Olivo, G.; Heredia, J.B. Flavonoids and Phenolic Acids from Oregano: Occurrence, Biological Activity and Health Benefits. Plants 2017, 7, 2. [CrossRef] [PubMed]

4. Gaspar, A.; Matos, M.J.; Garrido, J.; Uriarte, E.; Borges, F. Chromone: A valid scaffold in medicinal chemistry. Chem. Rev. 2014, 114, 4960-4992. [CrossRef] [PubMed]

5. Stefanachi, A.; Leonetti, F.; Pisani, L.; Catto, M.; Carotti, A. Coumarin: A Natural, Privileged and Versatile Scaffold for Bioactive Compounds. Molecules 2018, 23, 250. [CrossRef] [PubMed]

6. Borghi, S.M.; Carvalho, T.T.; Staurengo-Ferrari, L.; Hohmann, M.S.; Pinge-Filho, P.; Casagrande, R.; Verri, W.A., Jr. Vitexin inhibits inflammatory pain in mice by targeting TRPV1, oxidative stress, and cytokines. J. Nat. Prod. 2013, 76, 1141-1149. [CrossRef] [PubMed]

7. Miao, J.; Cui, H.; Jin, J.; Lai, F.; Wen, H.; Zhang, X.; Ruda, G.F.; Chen, X.; Yin, D. Development of 3-alkyl-6-methoxy-7-hydroxy-chromones (AMHCs) from natural isoflavones, a new class of fluorescent scaffolds for biological imaging. Chem. Commun. 2015, 51, 881-884. [CrossRef] [PubMed]

8. Giordano, L.; Shvadchak, V.V.; Fauerbach, J.A.; Jares-Erijman, E.A.; Jovin, T.M. Highly Solvatochromic 7-Aryl-3-hydroxychromones. J. Phys. Chem. Lett. 2012, 3, 1011-1016. [CrossRef] [PubMed]

9. Yan, N.; He, Y.; Wen, H.; Lai, F.; Yin, D.; Cui, H. A Suzuki-Miyaura method for labelling proliferating cells containing incorporated BrdU. Analyst 2018, 143, 1224-1233. [CrossRef] [PubMed]

10. Van Berkel, S.S.; Brem, J.; Rydzik, A.M.; Salimraj, R.; Cain, R.; Verma, A.; Owens, R.J.; Fishwick, C.W.; Spencer, J.; Schofield, C.J. Assay platform for clinically relevant metallo-beta-lactamases. J. Med. Chem. 2013, 56, 6945-6953. [CrossRef] [PubMed]

11. Ai, T.; Cui, H.; Chen, L. Multi-targeted histone deacetylase inhibitors in cancer therapy. Curr. Med. Chem. 2012, 19, 475-487. [CrossRef] [PubMed]

12. Cui, H.; Kamal, Z.; Ai, T.; Xu, Y.; More, S.S.; Wilson, D.J.; Chen, L. Discovery of potent and selective sirtuin 2 (SIRT2) inhibitors using a fragment-based approach. J. Med. Chem. 2014, 57, 8340-8357. [CrossRef] [PubMed]

13. Woronoff, G.; El Harrak, A.; Mayot, E.; Schicke, O.; Miller, O.J.; Soumillion, P.; Griffiths, A.D.; Ryckelynck, M. New generation of amino coumarin methyl sulfonate-based fluorogenic substrates for amidase assays in droplet-based microfluidic applications. Anal. Chem. 2011, 83, 2852-2857. [CrossRef] [PubMed]

14. Deng, J.; Yu, P.; Wang, Y.; Mao, L. Real-time ratiometric fluorescent assay for alkaline phosphatase activity with stimulus responsive infinite coordination polymer nanoparticles. Anal. Chem. 2015, 87, 3080-3086. [CrossRef] [PubMed]

15. Dziuba, D.; Karpenko, I.A.; Barthes, N.P.; Michel, B.Y.; Klymchenko, A.S.; Benhida, R.; Demchenko, A.P.; Mely, Y.; Burger, A. Rational design of a solvatochromic fluorescent uracil analogue with a dual-band ratiometric response based on 3-hydroxychromone. Chemistry 2014, 20, 1998-2009. [CrossRef] [PubMed]

16. Chevalier, K.; Grun, A.; Stamm, A.; Schmitt, Y.; Gerhards, M.; Diller, R. ESIPT and photodissociation of 3-hydroxychromone in solution: Photoinduced processes studied by static and time-resolved UV/Vis, fluorescence, and IR spectroscopy. J. Phys. Chem. A 2013, 117, 11233-11245. [CrossRef] [PubMed]

17. Roth, M.; Chen, W.Y. Sorting out functions of sirtuins in cancer. Oncogene 2014, 33, 1609-1620. [CrossRef] [PubMed]

18. Jing, H.; Lin, H. Sirtuins in epigenetic regulation. Chem. Rev. 2015, 115, 2350-2375. [CrossRef] [PubMed]

19. Wolf, G. Calorie restriction increases life span: A molecular mechanism. Nutr. Rev. 2006, 64 Pt 1, 89-92. [CrossRef] [PubMed]

20. Herskovits, A.Z.; Guarente, L. SIRT1 in neurodevelopment and brain senescence. Neuron 2014, 81, 471-483. [CrossRef] [PubMed] 
21. Serrano, L.; Martinez-Redondo, P.; Marazuela-Duque, A.; Vazquez, B.N.; Dooley, S.J.; Voigt, P.; Beck, D.B.; Kane-Goldsmith, N.; Tong, Q.; Rabanal, R.M.; et al. The tumor suppressor SirT2 regulates cell cycle progression and genome stability by modulating the mitotic deposition of H4K20 methylation. Genes Dev. 2013, 27, 639-653. [CrossRef] [PubMed]

22. Finnin, M.S.; Donigian, J.R.; Pavletich, N.P. Structure of the histone deacetylase SIRT2. Nat. Struct. Biol. 2001, 8, 621-625. [CrossRef] [PubMed]

23. Galleano, I.; Schiedel, M.; Jung, M.; Madsen, A.S.; Olsen, C.A. A Continuous, Fluorogenic Sirtuin 2 Deacylase Assay: Substrate Screening and Inhibitor Evaluation. J. Med. Chem. 2016, 59, 1021-1031. [CrossRef] [PubMed]

24. Schutkowski, M.; Fischer, F.; Roessler, C.; Steegborn, C. New assays and approaches for discovery and design of Sirtuin modulators. Expert Opin. Drug Discov. 2014, 9, 183-199. [CrossRef] [PubMed]

25. Smith, B.C.; Hallows, W.C.; Denu, J.M. A continuous microplate assay for sirtuins and nicotinamideproducing enzymes. Anal. Biochem. 2009, 394, 101-109. [CrossRef] [PubMed]

26. Fan, Y.; Ludewig, R.; Scriba, G.K. 9-Fluorenylmethoxycarbonyl-labeled peptides as substrates in a capillary electrophoresis-based assay for sirtuin enzymes. Anal. Biochem. 2009, 387, 243-248. [CrossRef] [PubMed]

27. Marcotte, P.A.; Richardson, P.L.; Guo, J.; Barrett, L.W.; Xu, N.; Gunasekera, A.; Glaser, K.B. Fluorescence assay of SIRT protein deacetylases using an acetylated peptide substrate and a secondary trypsin reaction. Anal. Biochem. 2004, 332, 90-99. [CrossRef] [PubMed]

28. Bitterman, K.J.; Anderson, R.M.; Cohen, H.Y.; Latorre-Esteves, M.; Sinclair, D.A. Inhibition of silencing and accelerated aging by nicotinamide, a putative negative regulator of yeast sir2 and human SIRT1. J. Biol. Chem. 2002, 277, 45099-45107. [CrossRef] [PubMed]

29. Disch, J.S.; Evindar, G.; Chiu, C.H.; Blum, C.A.; Dai, H.; Jin, L.; Schuman, E.; Lind, K.E.; Belyanskaya, S.L.; Deng, J.; et al. Discovery of thieno[3,2-d]pyrimidine-6-carboxamides as potent inhibitors of SIRT1, SIRT2, and SIRT3. J. Med. Chem. 2013, 56, 3666-3679. [CrossRef] [PubMed]

30. Friden-Saxin, M.; Seifert, T.; Landergren, M.R.; Suuronen, T.; Lahtela-Kakkonen, M.; Jarho, E.M.; Luthman, K. Synthesis and evaluation of substituted chroman-4-one and chromone derivatives as sirtuin 2-selective inhibitors. J. Med. Chem. 2012, 55, 7104-7113. [CrossRef] [PubMed]

31. Suzuki, T.; Khan, M.N.; Sawada, H.; Imai, E.; Itoh, Y.; Yamatsuta, K.; Tokuda, N.; Takeuchi, J.; Seko, T.; Nakagawa, H.; et al. Design, synthesis, and biological activity of a novel series of human sirtuin-2-selective inhibitors. J. Med. Chem. 2012, 55, 5760-5773. [CrossRef] [PubMed]

32. Zhou, Y.; Cui, H.; Yu, X.; Peng, T.; Wang, G.; Wen, X.; Sun, Y.; Liu, S.; Zhang, S.; Hu, L.; et al. Synthesis and Evaluation of Novel Benzofuran Derivatives as Selective SIRT2 Inhibitors. Molecules 2017, 22, 1348. [CrossRef] [PubMed]

33. Howitz, K.T.; Bitterman, K.J.; Cohen, H.Y.; Lamming, D.W.; Lavu, S.; Wood, J.G.; Zipkin, R.E.; Chung, P.; Kisielewski, A.; Zhang, L.L.; et al. Small molecule activators of sirtuins extend Saccharomyces cerevisiae lifespan. Nature 2003, 425, 191-196. [CrossRef] [PubMed]

34. Rasbach, K.A.; Schnellmann, R.G. Isoflavones promote mitochondrial biogenesis. J. Pharmacol. Exp. Ther. 2008, 325, 536-543. [CrossRef] [PubMed]

35. Dai, H.; Kustigian, L.; Carney, D.; Case, A.; Considine, T.; Hubbard, B.P.; Perni, R.B.; Riera, T.V.; Szczepankiewicz, B.; Vlasuk, G.P.; et al. SIRT1 activation by small molecules: Kinetic and biophysical evidence for direct interaction of enzyme and activator. J. Biol. Chem. 2010, 285, 32695-32703. [CrossRef] [PubMed]

36. Villalba, J.M.; Alcain, F.J. Sirtuin activators and inhibitors. Biofactors 2012, 38, 349-359. [CrossRef] [PubMed]

37. Mitchell, S.J.; Martin-Montalvo, A.; Mercken, E.M.; Palacios, H.H.; Ward, T.M.; Abulwerdi, G.; Minor, R.K.; Vlasuk, G.P.; Ellis, J.L.; Sinclair, D.A.; et al. The SIRT1 activator SRT1720 extends lifespan and improves health of mice fed a standard diet. Cell Rep. 2014, 6, 836-843. [CrossRef] [PubMed]

38. Hirasaka, K.; Maeda, T.; Ikeda, C.; Haruna, M.; Kohno, S.; Abe, T.; Ochi, A.; Mukai, R.; Oarada, M.; Eshima-Kondo, S.; et al. Isoflavones derived from soy beans prevent MuRF1-mediated muscle atrophy in C2C12 myotubes through SIRT1 activation. J. Nutr. Sci. Vitaminol. 2013, 59, 317-324. [CrossRef] [PubMed]

39. Hubbard, B.P.; Gomes, A.P.; Dai, H.; Li, J.; Case, A.W.; Considine, T.; Riera, T.V.; Lee, J.E.; E, S.Y.; Lamming, D.W.; et al. Evidence for a common mechanism of SIRT1 regulation by allosteric activators. Science 2013, 339, 1216-1219. [CrossRef] [PubMed] 
40. Cui, H.; Ruda, G.F.; Carrero-Lerida, J.; Ruiz-Perez, L.M.; Gilbert, I.H.; Gonzalez-Pacanowska, D. Exploring new inhibitors of Plasmodium falciparum purine nucleoside phosphorylase. Eur. J. Med. Chem. 2010, 45, 5140-5149. [CrossRef] [PubMed]

41. Wen, H.; Cui, Q.; Meng, H.; Lai, F.; Wang, S.; Zhang, X.; Chen, X.; Cui, H.; Yin, D. A high-resolution method to assess cell multinucleation with cytoplasm-localized fluorescent probes. Analyst 2016, 141, 4010-4013. [CrossRef] [PubMed]

42. Lai, F.; Shen, Z.; Wen, H.; Chen, J.; Zhang, X.; Lin, P.; Yin, D.; Cui, H.; Chen, X. A Morphological identification cell cytotoxicity assay using cytoplasm-localized fluorescent probe (CLFP) to distinguish living and dead cells. Biochem. Biophys. Res. Commun. 2017, 482, 257-263. [CrossRef] [PubMed]

43. Wang, S.; Gao, Y.; Shen, S.; Wen, H.; Cui, H. A Mild Aqueous Sonogashira Reaction as a Fluorescent Labeling Strategy for 5-Bromide-2'-Deoxyuridine. Molecules 2018, 23, 154. [CrossRef] [PubMed]

44. Williams, A.T.R.; Winfield, S.A.; Miller, J.N. Relative fluorescence quantum yields using a computer controlled luminescence spectrometer. Analyst 1983, 108, 1067-1071. [CrossRef]

Sample Availability: Samples of all compounds are available from the authors.

(c) 2018 by the authors. Licensee MDPI, Basel, Switzerland. This article is an open access article distributed under the terms and conditions of the Creative Commons Attribution (CC BY) license (http://creativecommons.org/licenses/by/4.0/). 